International Journal of Public Health Science (IJPHS)

Vol. 10, No. 4, December 2021, pp. 801 806

ISSN: 2252-8806, DOI: 10.11591/ijphs.v10i4.21147

\title{
Factors of mothers' hesitation in discussing reproductive health
}

\author{
Ratih Indraswari, Zahroh Shaluhiyah, Bagoes Widjanarko, Antono Suryoputro \\ Faculty of Public Health, Universitas Diponegoro, Semarang, Indonesia
}

\begin{tabular}{l} 
Article Info \\
\hline Article history: \\
Received Jul 14, 2021 \\
Revised Aug 14, 2021 \\
Accepted Aug 24, 2021 \\
\hline
\end{tabular}

\section{Keywords:}

Adolescent

Children

Mother

Reproductive health

Teenager

\begin{abstract}
Reproductive health is always becoming an issue for adolescence. Lack of knowledge, permissive attitude, easy access to pornography and low parental supervision reported as a determinant of risky sexual behavior in adolescence. This study aimed to investigate mother's perspectives in discussing reproductive health issues with their children aged 9-11 years old. The respondents were 8.046 mothers who had children aged 9-11 years old in Semarang, taken with a purposive sampling technique. Most mother (84.4\%) were in adulthood, graduated from Senior High School (50.8\%), unemployment $(44 \%)$, and $47.2 \%$ was in low-middle income family. As much as $26.8 \%$ of mothers agreed that it is not necessary to inform their children about reproductive health. Talking about reproductive health is taboo for $41.9 \%$ of mothers and $38.5 \%$ felt awkward. Most of them (71.7\%) encountered difficulties in starting reproductive health discussions with their children and $76.1 \%$ used other terms to name the genitals to feel more polite. A mother who perceived that delivering reproductive health information is unnecessary (OR 1.44), taboo (OR 1.82), awkward (OR 1.93), and giving courtship permission (OR 1.28) to their children significantly becoming risk factors in practicing reproductive health education. Health workers should help the mothers improve their communication skills, especially in discussing reproductive health with children aged 9-11 years old.
\end{abstract}

This is an open access article under the CC BY-SA license.

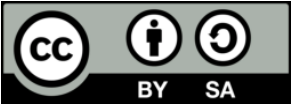

\section{Corresponding Author:}

Ratih Indraswari

Faculty of Public Health

Universitas Diponegoro

Jl. Prof. Soedarto, SH, Tembalang, Kec. Tembalang, Semarang, Central Java 50275, Indonesia

Email: ratih.indraswari@gmail.com

\section{INTRODUCTION}

Every year, about three million adolescent girls aged 15-19 years have an abortion [1]. More than half of all abortions are reported from Asia. In general, abortion in developed countries has decreased by $17 \%$. However, in developing countries, there has been an increase in abortion rates by around $11 \%$ [2]. The increased risk of abortion is influenced by the incidence of unwanted pregnancy [3]. On average every year in Indonesia there are 8\% of abortions performed by adolescent girls aged less than 19 years due to unwanted pregnancy [4].

Unwanted pregnancy in adolescents has also become a health problem in the world. Every year, approximately 16 million women aged 15-19 years and 2.5 million women under 16 years of age in developing countries experience childbirth [5]. Based on data from the 2015 Global School-based Health Survey (GSHS), $5.26 \%$ of junior and senior high school students in Indonesia have had sex. Only $13 \%$ of them using condoms consistently [6]. This is following data from the Indonesian Ministry of Health which states that the incidence of unwanted pregnancy in adolescents aged 15-19 years in Indonesia continues to increase, from 1.97\% of adolescents in 2013 [7], to 16.4\% in 2017 [8]. Pre-assessment in PKBI Central Java 
found that $40.6 \%$ of 64 adolescents with an unwanted pregnancy were adolescents who came from urban areas. Sexual behavior is significantly related to access to pornography [9]. Adolescent's access to magazines, books, pornographic films, and porno-action that describe the enjoyment of sex causes teenagers to have sex at an early age (13-15 years) [10]. Teenagers imitated friend's behavior or a sort of compulsion boost. Most of them got the pornography access from the internet and given also by their own friends [9].

Besides personal factors, sexual behavior in adolescents is strongly influenced by their environments, such as cultural norms, the role of parents and peers [9]. The low presence, involvement, and supervision of parents are proven to affect adolescents in having risky sexual behavior directly. Based on the adolescent reproductive health indicator in the 2017 Illinois Department of Human Services (IDHS), it was found that people who were invited to discuss issues related to reproductive health by adolescent girls were peers $(57.5 \%)$ and mothers $(45.2 \%)$ [11].

Parental-to-child supervision and communication affect risky sexual behavior in adolescents [12]. As much as $50 \%$ of parents reported not monitoring the activities of their teenagers and $63 \%$ providing free internet access without knowing the page being accessed [9]. Parents also refuse to talk about reproductive health because they are worried that their children will be moved to do things that are not desired. Apart from considering that the discussion is still taboo, parents feel that one day the child will understand by itself and give education to the school [13]. As with parents, previous research states that teachers feel awkward and embarrassed when they have to openly convey information related to reproductive health to students because they still consider it taboo [14].

GSHS data states that $27.35 \%$ of junior high and high school students in Indonesia have been active in sexual intercourse before they were 14 years old [6]. According to the IDHS, the percentage of adolescents who had sex for the first time between the ages of 15-19 increased from 59\% in 2012 to $74 \%$ in 2017. Meanwhile, $6 \%$ of adolescents reported making their sexual debut when they were 11-14 years old, which is the average age at the beginning of puberty or the transition from childhood to adolescence [8].

Based on the explanation above, information about reproductive health is greatly needed by children who are growing up. Perceived benefit becomes an indicator for a good communicator delivering a health message [15]. Unfortunately, there is no study in Indonesia pursuing the mother's perspective, as the main communicator, in discussing health reproductive matters with their children. This study aims to describe the perspective of mothers in conveying reproductive health information to their children and investigate its' influence factor.

\section{RESEARCH METHOD}

This research was cross-sectional study conducted on 8,046 mothers of children aged 9-11 years old in Semarang. Taken by purposive sampling, the criteria of this research respondent were the mother who had a child aged 9-11 years old, lived in Semarang City, Central Java, Indonesia and was willing to participate in this research. Due to the pandemic situation, we used a self-administered questionnaire in collecting the data by Google Forms and helped by the teacher from 327 public elementary schools in Semarang to share the link of the questionnaire to the student's parents through their class WhatsApp Group. Only mothers who met the criteria filled the questionnaire.

The independent variables were mother characteristics (age, education, occupation, income) and perspective in delivering reproductive health information to children. The dependent variable was the mother's practice in delivering reproductive health information. The data were analyzed by univariate to obtain a description of the mother's perspective as health communicators, and multivariate to investigate its risk factors. This research received the approval of the ethics committee of the Faculty of Public Health UNDIP through letter no 65/EA /KEPK-FKM/2021.

\section{RESULTS AND DISCUSSION}

Based on Table 1, most of the respondent is in adulthood (84.4\%). This is the phase of productive age. Mothers who are at the productive age are at the most crucial age and have solid activities [16]. At this time, mothers have good cognitive abilities. It means that age influences on the level of knowledge. The older a person is, the more mature she is in thinking and working [16]. Besides a cognitive perspective, age is also related to people's beliefs. Someone more mature will be trusted more than someone who is not mature enough. A person's age also affects one's comprehension and mindset. As she gets older, her perceptive power and mindset will also develop, so that the knowledge she gets should be better. There is no report about declining intellectual ability, problem solving, and verbal ability at this age [17]. It can be interpreted that mothers at productive ages should be able to become appropriate health communicators for their children. 
Table 1. Respondent's characteristic

\begin{tabular}{lcc}
\hline \multicolumn{1}{c}{ Characteristic } & $\mathrm{n}$ & $\%$ \\
\hline Age & 5 & 0.0 \\
Adolescent & 6,789 & 84.4 \\
Adult & 1,252 & 15.6 \\
Elderly & & \\
Education & 63 & 0.8 \\
$\quad$ No education & 760 & 9.4 \\
Elementary school & 1,275 & 15.8 \\
Junior school & 4,088 & 50.8 \\
High school & 778 & 9.7 \\
Diploma & 1,004 & 12.5 \\
Undergraduate & 78 & 1.0 \\
Postgraduate & & \\
Occupation & 3,544 & 44.0 \\
Unemployment & 222 & 2.8 \\
Civil servant/ Public employees/Army/Police & 1,470 & 18.3 \\
Private employees & 1,078 & 13.4 \\
Entrepreneur & 12 & 0.1 \\
Farmer & 2 & 0.0 \\
Fisherman & 697 & 8.7 \\
Labor/maid & 1,021 & 12.7 \\
Other & & \\
Family income & 3,794 & 47.2 \\
< minimum wage & 4,252 & 52.8 \\
> minimum wage & 8,046 & 100.0 \\
Total & &
\end{tabular}

Source: Primary data, 2021

Formal education is an educational path that is structured and tiered which consists of primary education, secondary education, and higher education. Half of mothers $(50.8 \%)$ in this study had graduated from high school. It means they have a secondary level of education, neither low nor high. The level of education is an important factor in honing skills. The educational process is expected to create educated humans who have a pattern of behavior following educational goals. Therefore the educational process is carried out in a system. Education makes a major contribution in interacting with the environment, skills, and knowledge acquired through school help facilitate a person's catching power in communicating. Community education affects their perceptions and conceptual abilities regarding the message received. In turn, it will also affect the arrangement of thoughts and feelings when implementing a response or provide feedback to the communicator or communicant [18]. Based on theory, people with higher education should communicate better in terms of content and attitudes. The communication ability of each mother will later be seen in how they behave. The whole human behavior is the result of learning, meaning that changes in the behavior of organisms as environmental influences [19].

This study reported that the majority of mothers are unemployment $(44 \%)$ and had family income more than regional minimum wage $(52.8 \%)$. In the patriarchal culture in Indonesia, it is natural to find the idea that men are the head of the household who work while women remain at home to look after children and complete household chores [20]. From this perspective, it is expected that stay-at-home mothers will have more free time than working mothers, but that is not entirely correct. Based on the pre-assessment, it is known that almost half of the respondents have a family income below the minimum wage; this is an economic burden that is greatly felt by the mother either. Instead of having the time in playing the role of health educator for their children, some mothers trying to engage in small businesses to make a living, but others choose to have time for them.

Table 2 shows that $85.3 \%$ of mothers answered that they knew the puberty status of their children and $89.8 \%$ limited children's relationships with the opposite sex. There were $12.7 \%$ of mothers who permitted their children to start having a close boy/girlfriend at that early age because it was considered a normal thing and $6 \%$ felt unnecessary to monitor their children's relationships. Monitoring is one of the parent's roles towards their children. Parents who monitor and supervise children's behavior mean that they check and maintain their children to have positive and beneficial activities. Children who lack parental monitoring will feel and act freely because there are no clear rules from their parents. Several previous studies have also proved that the lack of parental monitoring results in the behavior of accessing pornography and risky sex in children [9], [21], [22]. 
Table 2. Mother's perspective and practice in delivering reproductive health information

\begin{tabular}{|c|c|c|c|}
\hline Variable & Category & $\mathrm{n}$ & $\%$ \\
\hline \multirow[t]{15}{*}{ Perspective } & Feeling unnecessary & & \\
\hline & Yes & 2,157 & 26.8 \\
\hline & No & 5,889 & 73.2 \\
\hline & Feeling taboo & & \\
\hline & Yes & 3,372 & 41.9 \\
\hline & No & 4,674 & 58.1 \\
\hline & Feeling awkward & & \\
\hline & Yes & 3,095 & 38.5 \\
\hline & No & 4,951 & 61.5 \\
\hline & Unnecessary to monitor children's friendship & & \\
\hline & Yes & 482 & 6.0 \\
\hline & No & 7,564 & 94.0 \\
\hline & Giving courtship permission & & \\
\hline & Yes & 1,024 & 12.7 \\
\hline & No & 7,022 & 87.3 \\
\hline \multirow[t]{22}{*}{ Practice } & Knowing children's puberty status & & \\
\hline & Yes & 6,860 & 85.3 \\
\hline & No & 1,186 & 14.7 \\
\hline & Ever give information about reproductive health & & \\
\hline & Yes & 4,758 & 40.9 \\
\hline & No & 3,288 & 59.1 \\
\hline & Limit children's friendship with opposite sex friend & & \\
\hline & Yes & 7,223 & 89.8 \\
\hline & No & 823 & 10.2 \\
\hline & Use another term in naming genitals & & \\
\hline & Yes & 6,126 & 76.1 \\
\hline & No & 1,920 & 23.9 \\
\hline & Encounter difficulties to discuss & & \\
\hline & Yes & 5,771 & 71.7 \\
\hline & No & 2,275 & 28.3 \\
\hline & Mothers respond to children's questions & & \\
\hline & No response/change topic & 432 & 5.4 \\
\hline & Scolding the child & 84 & 1.0 \\
\hline & Explain honestly & 6,953 & 86.4 \\
\hline & Explain dishonestly & 101 & 1.3 \\
\hline & Others & 476 & 5.9 \\
\hline & Total & 8,046 & 100.0 \\
\hline
\end{tabular}

Source: Primary data, 2021

Mothers $(73.2 \%)$ felt the need to convey reproductive health information to their children, but $71.7 \%$ of mothers had difficulty starting discussions. This is because talking about reproductive health involving the genitals is still considered taboo (41.9\%) and mothers feel awkward if they have to discuss it $(38.5 \%)$. Previous research states that parents feel embarrassing and not confident in having discussions related to this issue [23], [24]. Mostly because parents perceive it as an adult affair and privacy, so this is what makes sex and reproductive health information considered taboo by some people in general [25]. Many mothers refuse to take part in this research immediately after knowing the research topic.

A previous study found that many parents did not receive reproductive education when they were young. This affects the refusal of parents to deliver reproductive health education to their children. They are not confident and worried if it may lead children to have experimented by themselves because of curiousness [23], [26], [27]. There are only $40.9 \%$ of mothers who have delivered reproductive health information to their children. As many as $86.4 \%$ admitted to providing honest health information to their children, but $76.1 \%$ of mothers used another term in referring to genitals. In Javanese society, the term commonly used in referring to the male genitalia (penis) is titit or manuk (bird). Words substitution is an attempt to translate taboo terms by replacing them using other words or phrases [28]. Sometimes, using this strategy is not giving the same arrangement but at least children can grasp a similar understanding of the content [29]. However, children will aware that discussion is not appropriate to talk to their mother because the mother manipulated the correct term. It will continue the taboo culture in talking sex education by parents and children. From the various explanations above, it can be concluded that mothers are hesitant in delivering reproductive health information to their children and do not provide information honestly.

Table 3 reports mothers who perceived that delivering reproductive health information is unnecessary (OR 1.44), taboo (OR 1.82), awkward (OR 1.93) and giving courtship permission (OR 1.28) to their children significantly becoming risk factors in practicing reproductive health education. Some research indicates that starting sex education in the early years is beneficial because parents find it easier to talk to 
children about sex when they are. It may even lead to reduce adolescent pregnancy. Poor parental communication and lack of skills and confidence are linked to poor sexual health among adolescents. The more educated the mother, the easier they discuss sexual and reproductive information with their children and the less likely the daughter ends up experiencing teenage pregnancy [30]. Non-negotiable thing is that sex and health reproductive health education should be delivered at an early age [24], [31].

Table 3. Logistic regression on mother's perspective toward practice in delivering reproductive health information

\begin{tabular}{|c|c|c|c|c|c|c|c|c|}
\hline \multirow[t]{2}{*}{ Variable } & \multirow[t]{2}{*}{ B } & \multirow[t]{2}{*}{$\mathrm{SE}$} & \multirow[t]{2}{*}{ Wald } & \multirow[t]{2}{*}{ df } & \multirow[t]{2}{*}{ Sig } & \multirow{2}{*}{$\begin{array}{l}\text { Exp } \\
\text { (B) }\end{array}$} & \multicolumn{2}{|c|}{$\begin{array}{l}95 \% \text { CI for Exp } \\
\text { (B) }\end{array}$} \\
\hline & & & & & & & Lower & Upper \\
\hline Feeling unnecessary & .365 & .048 & 58.518 & 1 & .000 & 1.440 & 1.312 & 1.581 \\
\hline Feeling taboo & .599 & .049 & 151.827 & 1 & .000 & 1.820 & 1.655 & 2.002 \\
\hline Feeling awkward & .655 & .048 & 183.270 & 1 & .000 & 1.925 & 1.751 & 2.117 \\
\hline Feeling unnecessary to monitor children's friendship & .060 & .081 & .552 & 1 & .457 & 1.062 & .906 & 1.245 \\
\hline Giving courtship permission & .247 & .057 & 18.620 & 1 & .000 & 1.280 & 1.144 & 1.432 \\
\hline
\end{tabular}

Source: Primary data, 2021

\section{CONCLUSION}

Most mothers believe that reproductive health information is important for their children, but they are hesitant to deliver or discuss those issues with their children. Mothers feel that talking about reproductive health issues is taboo. Mothers also feel awkward and face difficulties in discussing it with their children. Some mothers have tried to talk with children, but for the reasons above, the mother are unable to name genitalia with the actual terms. The government, through the Health Office and the Education Office, is expected to work together in providing communication skills to mothers so that they can convey reproductive health information correctly and confidently to their children so that children get the right source of information from the most trustworthy person. Good communication between parents and children will provide a positive bond, especially in later life when the children become adolescents.

\section{REFERENCES}

[1] J. Bearak, A. Popinchalk, L. Alkema, and G. Sedgh, "Global, Regional, and Subregional Trends in Unintended Pregnancy and Its Outcomes from 1990 to 2014: Estimates from a Bayesian Hierarchical Model," Lancet Glob. Heal., vol. 6, no. 4, pp. e380-e389, 2018, doi: 10.1016/S2214-109X(18)30029-9.

[2] B. Ganatra et al., "Global, Regional, and Subregional Classification of Abortions by Safety, 2010-14: Estimates from a Bayesian Hierarchical Model," Lancet, vol. 390, no. November 25, pp. 2372-81, 2017, doi: 10.1016/S01406736(17)31794-4.

[3] S. Singh et al., "The Incidence of Abortion and Unintended Pregnancy in India, 2015," Lancet Glob. Heal., vol. 6, no. 1, pp. 111-20, 2018, doi: 10.1016/S2214-109X(17)30453-9.

[4] D. Ocviyanti and M. Dorothea, “Aborsi di Indonesia," J. Indones. Med. Assoc., vol. 68, no. 6, pp. 213-215, 2018, doi: 10.47830/jinma-vol.68.6-2018-56.

[5] A. I. Ajayi, S. A. Odunga, C. Oduor, R. Ouedraogo, B. A. Ushie, and Y. D. Wado, "II was tricked': understanding reasons for unintended pregnancy among sexually active adolescent girls," Reprod. Health, vol. 18, no. 19, pp. 111, 2021, doi: 10.1186/s12978-021-01078-y.

[6] Ministry of Health of the Republic of Indonesia, "Health Risk Behavior in Middle and High School Students in Indonesia (In Indonesia: Perilaku Berisiko Kesehatan pada Pelajar SMP dan SMA di Indonesia)," 2015, [Online]. Available: https://www.who.int/ncds/surveillance/gshs/GSHS_2015_Indonesia_Report_Bahasa.pdf?ua=1.

[7] Ministry of Health of the Republic of Indonesia, "Adolescent Reproductive Health Situation (In Indonesia: Situasi Kesehatan Reproduksi Remaja)," Jakarta, 2015, [Online]. Available: https://pusdatin.kemkes.go.id/resources/download/pusdatin/infodatin/infodatin-reproduksi-remaja.pdf.

[8] Badan Kependudukan dan Keluarga Berencana Nasional, "Indonesia Demographic and Health Survey 2017: Youth Book. Jakarta, 2018, [Online]. Available: https://archive.org/details/LaporanSDKI2017Remaja.

[9] M. Ybarra and K. Mitchell, "Exposure to internet pornography among children and adolescents: a national survey, " CyberPsychology \& Behavior, vol. 8, no. 5, pp. 473-86, 2005, doi: 10.1089/cpb.2005.8.473.

[10] M. Flood, "The harms of pornography exposure among children and young people," Child Abuse Review, vol. 18, pp. 384-400, 2009, doi: 10.1002/car.1092.

[11] Badan Kependudukan dan Keluarga Berencana Nasional, "Indonesia Demographic and Health Survey 2017: Adolescent Reproductive Health (Key Indicator)," Jakarta: BKKBN, 2018, [Online]. Available : https://cis.bkkbn.go.id/latbang/?wpdmpro=indikator-utama-key-indicator-report-kespro-remaja-sdki-2017_idhs2017_english-version.

[12] M. Laili, H. Puspitawati, and L. Yuliati, "Is it parental Communication, self esteem, or internet use that makes pornography behavior in teenagers? (cases of pornography and porno-action)," Journal of Child Dev. Stu., vol. 3, 
no. 1, pp. 59-69, 2018, doi: 10.29244/JCDS.3.1.59-69.

[13] R. Hardani, D. Hastuti, and L. Yuliati, "Pornography behavior of Junior High School Student," Journal of Child Dev. Stu., vol. 3, no. 1, pp. 15-27, 2018, doi: 10.29244/JCDS.3.1.15-27.

[14] M. Motlagh, L. Rejaei, and A. Jonidi, "Priorities in Health Education Needs of Youth Based on Needs Assessment and Stakeholder Involvement, in Areas Covered by the Health Departments of Iran University of Medical Sciences," J. Educ. Community Heal., vol. 3, no. 1, pp. 51-57, 2016, doi: 10.21859/jech-03017.

[15] R. Schiavo, "Health Communication: from theory to practice," Journal of the Med. Library. Assoc, vol. 96, no. 1, , pp 72-73, 2008, doi: 10.3163/1536-5050.96.1.72.

[16] I. J. Deary, J. Corlet, A. J. Gow, and S. E. Harris, “Age-associated cognitive decline,” Br. Med. Bull., vol. 92, no. 1, pp. 135-52, 2009, doi: 10.1093/bmb/ldp033.

[17] R. Correia, J. Barroso, and A. Nieto, "Age-Related Cognitive Changes: The Importance of Modulating Factors," J. Geriatr. Med. Gerontol., vol. 4, no. 2, pp. 1-10, 2018, doi: 10.23937/2469-5858/1510048.

[18] V. Navickiene, Ž. Sederevičiūtè-Pačiauskienè, I. Valantinaitè, and V. Zilinskaite, "The relationship between communication and education through the creative personality of the teacher," Creat. Stud., vol. 12, no. 1, pp. 4960, 2019, doi: $10.3846 / \mathrm{cs} .2019 .6472$.

[19] S. O. Obaki, "Impact of Classroom Environment on Children's Social Behavior," Int. J. Educ. Pract., vol. 5, no. 1, pp. 1-7, 2017, doi: 10.18488/journal.61/2017.5.1/61.1.1.7.

[20] A. N. Sigiro, "Care Economy and the Burden of Housewives' Work in Indonesia," J. Peremp., vol. 23, no. 4, p. 249, 2018, doi: 10.34309/jp.

[21] S. P. E. Dávila, J. Champion, M. G. Monsiváis, M. Tovar, and M. L. F. Arias, "Mexican Adolescents' Self-Reports of Parental Monitoring and Sexual Communication for Prevention of Sexual Risk Behavior," J. Pediatr. Nurs., vol. 35, pp. 83-89, 2017, doi: 10.1016/j.pedn.2017.03.007.

[22] A.C. Davis, C. J. C. Wright, M. Curtis, and M.E. Hellard, "Not my child: Prenting, pornography, and views on education," Journal of Family Studies, September, 2019, doi: 10.1080/13229400.2019.1657929.

[23] H. Shin, J. M. Lee, and J. Y. Min, "Sexual Knowledge, Sexual Attitudes, and Perceptions and Actualities of Sex Education among Elementary School Parents," Child Heal. Nurs. Res., vol. 25, no. 3, pp. 312-23, 2019, doi: 10.4094/chnr.2019.25.3.312.

[24] K. H. Robinson, E. Smith, and C. Davies, "Responsibilities, tensions and ways forward: parents' perspectives on children's sexuality education," Sex Educ., vol. 17, no. 3, pp. 333-47, 2017, doi: 10.1080/14681811.2017.1301904.

[25] R. Runcan and A. Bahnaru, "Sex Education Revisited: School-based Sex Education," Analele Univ. din Craiova, vol. 18 , no. 1, pp. 1-7, 2019.

[26] A. Aventin et al., "Engaging parents in digital sexual and reproductive health education: evidence from the JACK trial," Reprod. Health, vol. 17, no. 132, pp. 1-18, 2020, doi: 10.1186/s12978-020-00975-y.

[27] A. Othman et al., "Parent-child communication about sexual and reproductive health: perspectives of Jordanian and Syrian parents," Sex. Reprod. Heal. Matters, vol. 28, no. 1, pp. 313-323, 2020, doi: 10.1080/26410397.2020.1758444.

[28] N. Robati, F. Zahra, and F. Zand, "Translation of Taboos: The Absolutely True Diary of a Part Time Indian,” Int. J. Appl. Linguist. English Lit., vol. 7, no. 3, pp. 35-40, 2018, doi: 10.7575/aiac.ijalel.v.7n.3p.35.

[29] M. Khoshsaligheh, "A Socio-cultural Study of Taboo Rendition in Persian Fansubbing: An Issue of Ressistance," Lang. Intercult. Commun., vol. 18, no. 6, pp. 663-80, 2018, doi: 10.1080/14708477.2017.1377211.

[30] N. Azira, F. B. Abdullah, S. M. Muda, and N. M. Zain, "The role of parents in providing sexuality education to their children children," Makara J. Heal. Res., vol. 24, no. 3, pp. 157-63, 2020, doi: 10.1363/3911607.

[31] N. M. Nambambi and P. Mufune, "What Is Talked About When Parents Discuss Sex with Children: Family Based Sex Education In Windhoek, Namibia," Afr. J. Reprod. Health, vol. 15, no. 4, pp. 120-9, 2011. 